\title{
A Rare Cause of Torticollis in Children: Atlantoaxial Rotatory Subluxation
}

\section{Çocuklarda Nadir Bir Tortikolis Nedeni: Atlantoaksiyel Rotatuar Subluksasyon}

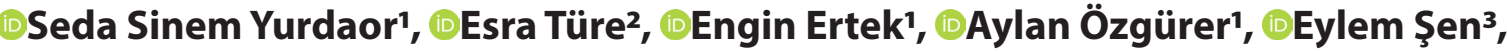 \\ ๑Ebru Tayfun Şentürk ${ }^{3}$, @Berna Aktürk ${ }^{3}, \oplus$ Aynur Karaca $^{3}$ \\ 'Department of Emergency, Bursa City Hospital, Bursa, Turkey \\ 2Department of Pediatric Emergency, Bursa City Hospital, Bursa, Turkey \\ ${ }^{3}$ Department of Pediatrics, Bursa City Hospital, Bursa, Turkey
}

\begin{abstract}
Torticollis is one of the common causes of admission to the emergency department among children which can make parents worried. This could be related to many traumatic and non-traumatic conditions. One of the rare causes of acute onset of torticollis is atlantoaxial rotatory subluxation, which is characterized by limitation of neck rotation, increased pain by movement. It is generally associated with a past trauma history. Although it is known as a temporary and self-resolving condition, if it is not diagnosed earlier it may lead to severe rotational deformity of the cervical spine. Therefore, detecting certain causes and providing proper treatment are highly important. Physical examination and history are usually enough to make the diagnosis, yet cervical $X$-ray and CT scan can be considered for indefinite cases. Even though treatment options depend on symptoms and the patient's general status, conservative approach with cervical collar and antiinflammatory drugs are recommended as a first step. We would like to present our case, a 13 year-old girl who has been diagnosed with atlantoaxial rotatory subluxation in our clinic to increase awareness of this condition which is often misdiagnosed in children.
\end{abstract}

Keywords: Atlantoaxial rotatory subluxation, children, torticollis, pediatric emergency

\section{INTRODUCTION}

First and second cervical vertebrae (C1-C2) and their ligaments are the crucial structures for neck movements. ${ }^{[1]}$ Important structures, such as transverse ligament, synovial capsule and tectorial membrane are located here to stabilize the joint and provide support for movement. Amount of these types of soft tissue components is greater in children

\section{Öz}

Tortikollis, özellikle aileleri endişelendirebilmesi nedeniyle, çocuklarda yaygın acile başvuru nedenlerinden birisidir. Bu durum travmatik veya non travmatik olmak üzere pek çok durumla ilişkili olabilir. Ani başlangıçlı tortikolisin nadir nedenlerinden biri de, boyunda rotasyon kısıtlıığı ve hareketle artan ağıı ile karakterize olan atlantoaksiyel rotasyonel subluksasyondur. Genellikle geçirilmiş bir travma öyküsü ile ilişkilidir. Geçici ve kendini sınıllayan bir durum olarak bilinse de, erken tanı konmadığı takdirde ciddi rotasyon deformitelerine neden olabilmektedir. Bu sebeple, nedeni saptamak ve uygun tedaviyi sunmak oldukça önemlidir. Tanı için fizik muayene ve anamnez büyük ölçüde yeterli olsa da, arada kalınmış vakalarda direkt grafi ve bilgisayarlı tomografi göz önünde bulundurulabilir. Tedavi seçenekleri semptomlara ve hastanın genel durumuna göre değişmekle birlikte, ilk aşama olarak boyunluk kullanımı ve anti inflamatuar ilaçlarla konservatif yaklaşım önerilir. Çocuk yaş grubunda çoğunlukla atlanan bu tanı açısından farkındalığı artıımak adına, kliniğimizde atlantoaksiyel rotatuar subluksasyon tanısı koyduğumuz 13 yaşındaki kız hastamızı sunmak istedik.

Anahtar Kelimeler: Atlantoaksiyel rotatuar subluksasyon, çocuk, tortikolis, pediatrik acil

than adults, therefore they can be affected by environmental factors easily and that can lead to more frequent clinical findings. ${ }^{[2,3]}$ The main difference between atlantoaxial rotatory subluxation (AARS) and normal cervical movement is the limitation in returning to the natural position of $\mathrm{C} 1-\mathrm{C} 2$ facet joints which can cause torticollis. ${ }^{[4]}$ 
Many traumatic or nontraumatic factors may play a role in etiology. Hence, a detailed history should be taken initially. In case of a trauma suspicion, appropriate position should be given, then the dislocations and fractures which may cause life threatening situations should be ruled out. ${ }^{[5]}$

Except from trauma, past infection history, autoimmune inflammatory diseases should also be investigated. There are many cases in the literature that develop following head and neck infections. ${ }^{[6-8]}$ With this case report, our aim is to address the issue of AARS, increase awareness about the situation, and help to provide early diagnosis and treatment for patients.

\section{CASE}

A 13-year-old girl was admitted to our pediatric emergency clinic complaining with severe neck pain and limitation of neck movements for 2 days. It was said that there was no known trauma history but the pain started after jumping rope. Patient's general status was good, she was conscious, oriented and cooperated. Her vital findings were normal and her past medical history and family history were unremarkable. There was no neurological deficit and sensitivity was not detected in the spinal process. There was rotation restriction to the lesion side and pain increasing with movement. Other system examinations were normal. The head was fixed in the appropriate position and further investigations were planned. Blood results were within normal range. Cervical computed tomography (CT) was ordered due to suspicious appearance on the cervical X-ray that may correspond to listhesis of cervical vertebrae (Figure 1). The patient's age, clinic, vague trauma history, imaging results were assessed as atlantoaxial rotatory subluxation.

Neurosurgery consultation was requested, and treatment was arranged with a nelson-type cervical collar and an appropriate dose of nonsteroidal anti-inflammatory drugs (NSAIDs). She was discharged to continue follow-up in an outpatient clinic. The patient, who has not had any complaints in follow-ups, recovered without any sequelae.

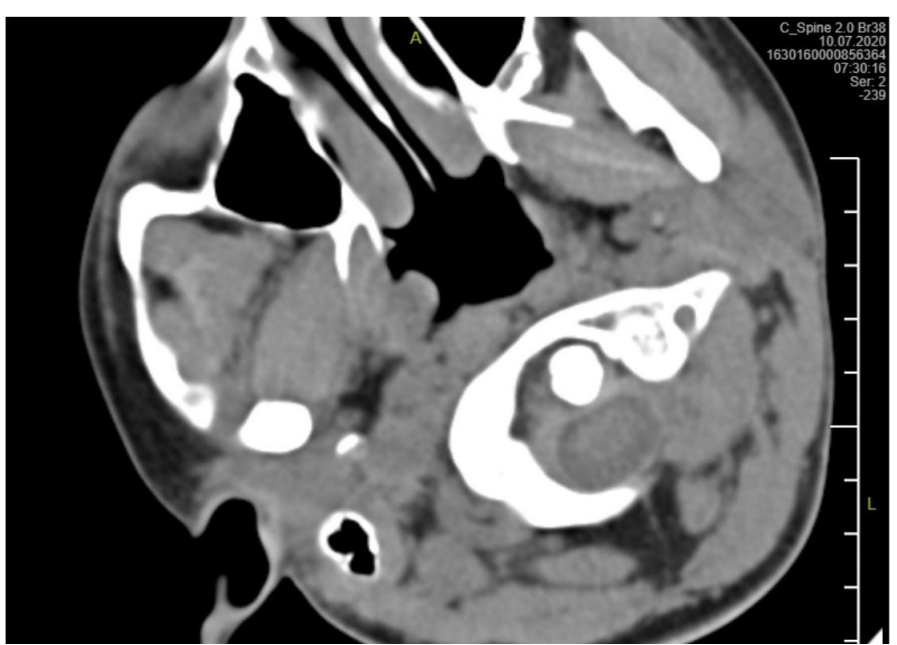

Figure 1. Cervical computed tomography image of Atlantoaxial Rotatory Subluxation

\section{DISCUSSION}

Atlantoaxial rotatory subluxation is a rare condition in which patients present with the new onset of torticollis. AARS represents a spectrum of disease from muscle spasm to a fixed mechanical block to reduction of the atlantoaxial complex. [4] The most important point in the diagnosis of atlantoaxial rotatory subluxation is to detect the underlying cause as early as possible and to make a follow-up and treatment plan for it. The most important step for a correct diagnosis is suspicion, as in all diseases. AARS should always be considered in patients who have a severe neck pain and limitation of neck movements and whose clinic features do not resolve despite symptomatic treatment. Although history and physical examination are generally enough to make the diagnosis, cervical X-ray may also be recommended to rule out life threatening conditions. ${ }^{[9]}$ Cervical CT scan is considered in patients with ongoing clinical suspicion. ${ }^{[5]}$ Treatment options depend on the patient's general condition, however most of the cases tend to be self-limiting. NSAIDs and cervical collars alongside rest are recommended as a first stage of treatment. [5] Hospitalization may be required for advanced treatment methods such as cervical traction or surgical interventions in patients whose complaints do not regress. ${ }^{[8]}$ Publications have shown that most of the patients recovered with conservative treatment without any sequelae, as in our case, and further treatment methods were needed in very few of them. ${ }^{[8]}$

Atlantoaxial rotatory subluxation is a condition that should be considered as a differential diagnosis, especially in children presenting with neck pain and restricted rotation. The fact that it is not a relatively common condition and the milder progress in children may cause this diagnosis to be missed, especially in intensive emergency services. Once detected early and given proper treatment, recovery can be achieved without sequelae, but it may cause serious anatomical and structural deformities in patients whose diagnosis is delayed, who do not receive appropriate treatment or left uncontrolled. [10] Therefore, an appropriate treatment plan and close followup are very important for an effective recovery.

\section{CONCLUSION}

It is very important for physicians working in pediatric emergency services to be suspicious of AARS in patients present with neck pain and abnormal head-neck position with a difficulty in returning to the neutral position, in terms of providing early diagnosis and treatment.

\section{ETHICAL CONSIDERATIONS}

Informed Consent: Written informed consent was obtained from all participants who participated in this study.

Status of Peer-review: Externally peer-reviewed.

Conflict of Interest Statement: The authors have no conflicts of interest to declare. 
Financial Disclosure: The authors declared that this study has received no financial support.

Author Contributions: All of the authors declare that they have all participated in the design, execution, and analysis of the paper, and that they have approved the final version.

\section{REFERENCES}

1. Pang D, Li V. Atlantoaxial rotatory fixation: Part 1--Biomechanics of normal rotation at the atlantoaxial joint in children. Neurosurgery. 2004;55(3):614-26.

2. Tubbs RS, Hallock JD, Radcliff V, et al. Ligaments of the craniocervical junction. J Neurosurg Spine. 2011;14(6):697-709.

3. Tang CH, Chiu YC, Tan TW, Yang RS, Fu WM. Adiponectin enhances IL-6 production in human synovial fibroblast via an AdipoR1 receptor, AMPK, p38, and NF-kappa B pathway. J Immunol. 2007;179(8):5483-92.

4. Neal KM, Mohamed AS. Atlantoaxial rotatory subluxation in children. J Am Acad Orthop Surg. 2015;23(6):382-92.

5. Sferopoulos NK. Atlantoaxial rotatory subluxation in children: A review. J Radiol Med Imaging 2018; 2: 1009.

6. Pang D, Li V. Atlantoaxial rotatory fixation: part 2--new diagnostic paradigm and a new classification based on motion analysis using computed tomographic imaging. Neurosurgery. 2005;57(5):941-53.

7. Bredenkamp JK, Maceri DR. Inflammatory torticollis in children. Arch Otolaryngol Head Neck Surg. 1990;116(3):310-3.

8. Subach BR, McLaughlin MR, Albright AL, Pollack IF. Current management of pediatric atlantoaxial rotatory subluxation. Spine (Phila Pa 1976). 1998;23(20):2174-9.

9. Samartzis D, Shen FH, Herman J, Mardjetko SM. Atlantoaxial rotatory fixation in the setting of associated congenital malformations: a modified classification system. Spine (Phila Pa 1976). 2010;35(4):119-27.

10. Schwarz $\mathrm{N}$. The fate of missed atlanto-axial rotatory subluxation in children. Arch Orthop Trauma Surg. 1998;117(4-5):288-9. 